WSRC-TR-2004-00035, Rev. 0

\title{
Carbon Steel and Magnesium Oxide Dissolution for H-Canyon Process Applications
}

KEYWORDS:

Carbon Steel

Dissolution

Nitric Acid

Fluoride

Boron

Robert A. Pierce

January 2004 
This document was prepared in conjunction with work accomplished under Contract No. DE-AC09-96SR18500 with the U. S. Department of Energy.

\section{DISCLAIMER}

This report was prepared as an account of work sponsored by an agency of the United States Government. Neither the United States Government nor any agency thereof, nor any of their employees, makes any warranty, express or implied, or assumes any legal liability or responsibility for the accuracy, completeness, or usefulness of any information, apparatus, product or process disclosed, or represents that its use would not infringe privately owned rights. Reference herein to any specific commercial product, process or service by trade name, trademark, manufacturer, or otherwise does not necessarily constitute or imply its endorsement, recommendation, or favoring by the United States Government or any agency thereof. The views and opinions of authors expressed herein do not necessarily state or reflect those of the United States Government or any agency thereof.

This report has been reproduced directly from the best available copy.

Available for sale to the public, in paper, from: U.S. Department of Commerce, National Technical Information Service, 5285 Port Royal Road, Springfield, VA 22161, phone: (800) 553-6847, fax: (703) 605-6900

email: orders@ntis.fedworld.gov

online ordering: http://www.ntis.gov/help/index.asp

Available electronically at http://www.osti.gov/bridge

Available for a processing fee to U.S. Department of Energy and its contractors, in paper, from: U.S. Department of Energy, Office of Scientific and Technical Information, P.O. Box 62, Oak Ridge, TN 37831-0062,

phone: (865)576-8401,

fax: (865)576-5728

email: $\underline{\text { reports@ adonis.osti.gov }}$ 


\section{SUMMARY}

H-Area Operations is planning to process plutonium-contaminated (Pu-contaminated) uranium metal scrap in its efforts to de-inventory excess nuclear materials. The Actinide Technology Section of the Savannah River Technology Center (SRTC) performed flowsheet development to support the processing the scrap in $\mathrm{H}$-Canyon using $2 \mathrm{M}$ nitric acid $\left(\mathrm{HNO}_{3}\right) / 0.025 \mathrm{M}$ potassium fluoride (KF) and $2 \mathrm{~g} / \mathrm{L}$ boron. The scrap will be charged to the H-Canyon dissolver via a stainless steel charging bundle with a carbon steel bundle end cap that must dissolve.

Experimental work was performed with a range of potential materials to be used to fabricate the bundle end cap to assess their dissolution characteristics in $2{\mathrm{M} \mathrm{HNO}_{3} /}^{\prime}$ $0.025 \mathrm{M} \mathrm{KF}$ and $2 \mathrm{~g} / \mathrm{L}$ boron. The sample compositions were made of different, unknown types of carbon steel. Experiments also measured the amount of hydrogen gas generated during carbon steel dissolution.

Several variables related to carbon steel dissolution have been evaluated using various materials that may be used in the fabrication of a dissolver bundle end cap for plutoniumcontaminated scrap processing. The variables evaluated include sample material, agitation, effect of a coating, and temperature.

The dissolution rate data fall into three basic ranges: plate/bar, wire/rivet, and can material. The room-temperature, unstirred dissolution rates were: plate/bar, 0.7-1.7

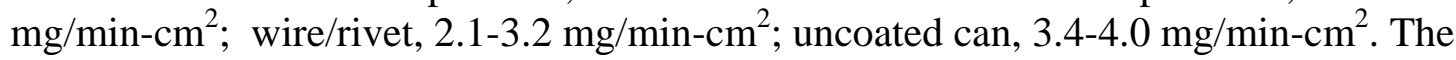
difference in rates shows the compositional differences between the samples. Sample hardness data show no correlation to the dissolution rates for the three categories. Calculated densities show that the can materials are clearly different than the plate/bar and wire/rivet materials. These dissolution rates increase by at least an order of magnitude at $100^{\circ} \mathrm{C}$.

Stirring can provide a three- to four-fold increase in dissolution rate when compared to static conditions. As carbon steel dissolves, it forms an oxide that does not readily dissolve in the absence of stirring. The accumulation of iron oxide near the dissolution surface diminishes the overall dissolution rate.

The effect of tin coatings on the food-pack cans is expected to be minimal. The data show that the coating reduces the initial dissolution rate by about one-third. However, because the coating is very thin, it is removed within a few seconds to a few minutes. Therefore, its effect on the overall dissolution rate of the can will be negligible.

Gas generation rates for the dissolution of carbon steel in $2 \mathrm{M} \mathrm{HNO}_{3} / 0.025 \mathrm{M} \mathrm{KF}$ and 2 $\mathrm{g} / \mathrm{L}$ boron reflected those observed for the dissolution of uranium metal. At room temperature, the amount of gas generated was not measurable due to solubility of the reaction products. At $95^{\circ} \mathrm{C}$, the measured gas generation was on the order of $250 \mathrm{~mL}$ per gram of carbon steel dissolved. At room temperature and $95^{\circ} \mathrm{C}$, the gases generated are predominantly a mixture of nitric oxide and nitrogen dioxide. Gas chromatography data 
demonstrate that hydrogen concentrations were below the instrument detection limit of $0.1 \%$ for both reaction temperatures.

Because the potential exists for magnesium oxide (MgO) to be introduced into the dissolution flowsheet, supplemental studies were conducted to evaluate the dissolution behavior of $\mathrm{MgO}$ sand and its effect on uranium metal dissolution rates. The dissolution of magnesium oxide (MgO) sand at room temperature in $2 \mathrm{M} \mathrm{HNO}_{3} / 0.025 \mathrm{M} \mathrm{KF}$ and 2 $\mathrm{g} / \mathrm{L}$ is very slow. Upon heating to $100^{\circ} \mathrm{C}$, more than $90 \%$ of the sand dissolves within one hour. After five hours at $100^{\circ} \mathrm{C}$, essentially all MgO sand has dissolved. The dissolution rate of uranium metal at room temperature into $2 \mathrm{M} \mathrm{HNO}_{3} / 0.025 \mathrm{M} \mathrm{KF}$ with 2 $\mathrm{g} / \mathrm{L}$ dissolved boron and $1.8 \mathrm{~g} / \mathrm{L}$ dissolved $\mathrm{MgO}$ showed no decrease due to the presence of dissolved MgO. 


\section{INTRODUCTION}

H-Area Operations is planning to process plutonium-contaminated uranium metal scrap in its efforts to de-inventory excess nuclear materials. The Actinide Technology Section of the Savannah River Technology Center (SRTC) performed flowsheet development to support the decision to process the scrap in $\mathrm{H}$-Canyon using $2 \mathrm{M}$ nitric acid $\left(\mathrm{HNO}_{3}\right) /$ $0.025 \mathrm{M}$ potassium fluoride (KF) and $2 \mathrm{~g} / \mathrm{L}$ boron. The scrap will be charged to the $\mathrm{H}$ Canyon dissolver via a stainless steel charging bundle with a carbon steel end cap that must dissolve in an appropriate time frame.

Experimental work was performed with a range of potential materials to be used to fabricate the bundle end cap. Testing was conducted with samples of metal plate, wire, cans, rods, and rivets to assess their dissolution characteristics in $2 \mathrm{M} \mathrm{HNO}_{3} / 0.025 \mathrm{M} \mathrm{KF}$ and $2 \mathrm{~g} / \mathrm{L}$ boron. Experiments also measured the amount of hydrogen gas generated during carbon steel dissolution using the above dissolver solution. Each material type and its associated dissolution characteristic relate to specific bundle end cap designs being considered.

Supplemental studies were conducted to evaluate the behavior and effect of magnesium oxide $(\mathrm{MgO})$ sand on dissolution of uranium metal in $2 \mathrm{M} \mathrm{HNO}_{3} / 0.025 \mathrm{M} \mathrm{KF}$ and $2 \mathrm{~g} / \mathrm{L}$ boron. The potential exists for a small quantity of $\mathrm{MgO}$ to be introduced into the dissolution flowsheet due to the use of $\mathrm{MgO}$ sand to extinguish uranium metal fires.

\section{EXPERIMENTAL}

Carbon Steel Dissolution Rates: Dissolution rates were all measured in $2 \mathrm{M}^{\mathrm{HNO}_{3}}$ / $0.025 \mathrm{M} \mathrm{KF}$ and $2 \mathrm{~g} / \mathrm{L}$ boron. Two temperatures were tested: $23-25^{\circ} \mathrm{C}$ and $100-102^{\circ} \mathrm{C}$. Many different samples of carbon steel and aluminum parts were tested. The samples were pieces of plate, wire, rivets with shanks, and standard materials that could be used to fabricate the bundle end cap.

Dissolution rates were measured as follows. A piece to be dissolved was weighed to 0.0001 grams and its physical dimensions were measured using digital calipers accurate to $0.01 \mathrm{~mm}$. The dimensions and weights were used to estimate sample density. Descriptions and dimensions of all samples dissolved are contained in Attachment 1.

Solution of $2 \mathrm{M} \mathrm{HNO}_{3} / 0.025 \mathrm{M} \mathrm{KF}$ and $2 \mathrm{~g} / \mathrm{L}$ boron was placed in a beaker with a stir bar and Type $\mathrm{K}$ thermocouple (inside a glass thermowell). In some instances, stirring was not used during dissolution. The beaker was covered with a watch glass with water in it to minimize solution evaporation. The acid solution was brought to temperature. Once at temperature, a sample was placed in the beaker and allowed to dissolve for a fixed amount of time. At the end of the specified dissolution time, the sample was withdrawn from solution, rinsed with water, dried and weighed. Because the primary dimension change is that of thickness (by a few percent), which accounts for very little of the exposed surface area, surface area is not re-measured after dissolution. Dissolution rate was determined as weight loss per unit surface area per unit time. 
Dissolution of tin-coated can materials occurred in two steps. In the first step, the tin (Sn) coating was dissolved along with some carbon steel over a short period of time ( $~ 5$ minutes). The second step evaluated the dissolution of only the carbon steel beneath the Sn coating. The dissolution tests were conducted in the manner discussed above.

Data were collected, where possible, of metal hardness using Rockwell Hardness testing. It is standard technique to test each sample in triplicate. The data reported are an average of the three values collected. Rockwell Hardness may be useful in assessing sample composition.

Carbon Steel Dissolution Gas Generation: Tests were performed to measure both the generation rates and measure the amount of hydrogen gas during the dissolution of carbon steel in $2 \mathrm{M} \mathrm{HNO}_{3} / 0.025 \mathrm{M} \mathrm{KF}$ and $2 \mathrm{~g} / \mathrm{L}$ boron. Of particular interest is the amount of hydrogen gas generated per mass of metal dissolved.

A system was set up as shown in Figure 1. The system was a sealed glass vessel designed to prevent the introduction or loss of gas. The vessel was filled with $500 \mathrm{~mL}$ of liquid to fill the majority of the $680 \mathrm{~mL}$ of space in the system. The liquid was brought to temperature - one test was performed at room temperature and another at $95^{\circ} \mathrm{C}$. The test used $95^{\circ} \mathrm{C}$ instead of $100^{\circ} \mathrm{C}$ because it was understood that the reaction would be rapid and produce both a temperature increase in the solution and significant evaporation from the solution. Evaporation would distort the total gas generation volume and possibly affect the gas composition. Once at temperature, the headspace and lines of the system were purged with $\mathrm{CO}_{2}$ gas.

After the system had been purged, a weighed carbon steel sample was added to the vessel and the vessel was sealed. The

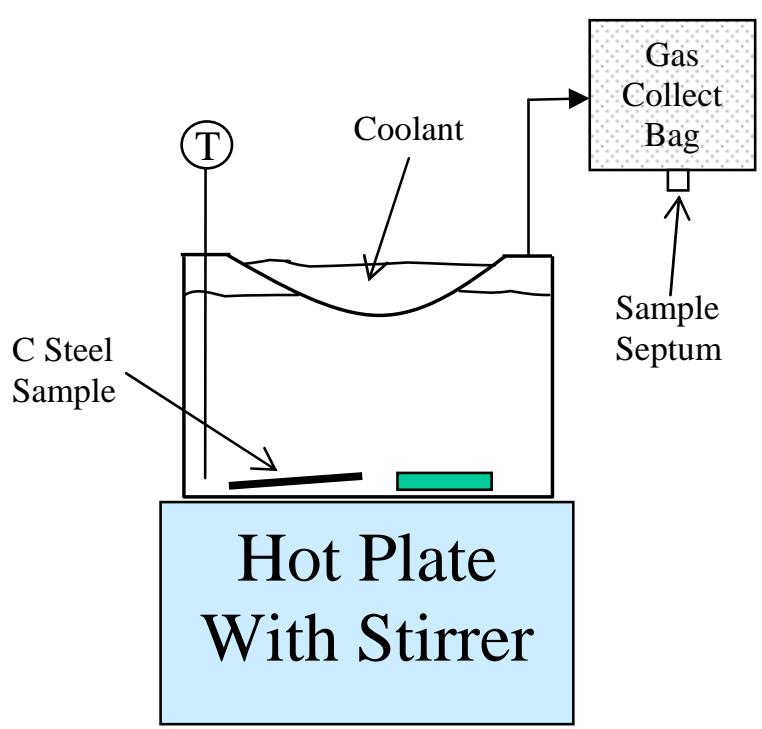

Figure 1. Gas Generation Setup sample sat on the bottom of the vessel. As gases were generated, they were collected in a gas-sample bag fitted with a valve and sample septum. After the metal sample had dissolved and gas generation had ceased, $10 \mathrm{~mL}$ of gas sample were collected in a syringe and the residual gas volume was measured using displacement of water by the gas collection bag. The gas sample was analyzed for hydrogen using gas chromatography.

Effect of $\mathrm{MgO}$ on Uranium Metal Dissolution: Supplemental studies were performed to evaluate the behavior and effect of $\mathrm{MgO}$ sand on uranium metal dissolution. The amount of $\mathrm{MgO}$ sand added was based on a maximum $\mathrm{MgO}$ sand concentration of 8 liters of sand in a 7500 -liter batch of acid. In the test, $500 \mathrm{~mL}$ of $2 \mathrm{M} \mathrm{HNO}_{3} / 0.025 \mathrm{M} \mathrm{KF}$ and $2 \mathrm{~g} / \mathrm{L}$ 
boron were prepared and placed in a beaker. Using a measured $\mathrm{MgO}$ sand bulk density of $1.68 \mathrm{~g} / \mathrm{mL}, 0.90$ grams of $\mathrm{MgO}$ sand were added to the $500 \mathrm{~mL}$ of acid at room temperature. The solution was stirred for five hours and periodic observations were made.

Since no observable dissolution of $\mathrm{MgO}$ sand occurred in the above test, the solution was heated to $100^{\circ} \mathrm{C}$ and stirring continued. The solution was maintained at $100^{\circ} \mathrm{C}$ for five hours. Periodic observations were made to assess the completeness of $\mathrm{MgO}$ sand dissolution.

After the $\mathrm{MgO}$ sand dissolution test, $200 \mathrm{~mL}$ of liquid from the test were used to assess the effect of $\mathrm{MgO}$ sand on uranium metal dissolution rates. The dissolution rate was measured as follows. A small piece of uranium metal plate was cut from a larger piece. The small piece was then pickled in acid at room temperature for 3-4 minutes to remove the oxide coating. Rate testing with the presence of the oxide coating is not necessary because earlier flowsheet studies demonstrated that the oxide coating dissolves readily. ${ }^{1}$

The physical dimensions (width, length, thickness, mass) of the sample were then measured. A balance was used to measure weight; calipers were used to measure width, length, and thickness. It is important to note that the balance in the glovebox measures only to 0.001 grams. Therefore, the uncertainty on small weight changes can be large.

Next, a beaker was filled with a known amount of dissolver solution from the MgO san dissolution test and placed on a hot plate/stirrer. The beaker also contained a sample holder to allow solution access to both sides of the sample without interfering with the stirring. The pickled uranium metal sample was placed in solution for a measured amount of time. At the end of the test, the metal sample was removed, rinsed with water, dried, and weighed. Uranium metal dissolution rate was determined as weight loss per unit surface area per unit time.

\section{RESULTS AND DISCUSSION}

Carbon Steel Dissolution Rates: The first set of tests focused on dissolution at both room temperature $\left(23^{\circ} \mathrm{C}\right)$ and at $100-102^{\circ} \mathrm{C}$. Later tests only investigated room temperature dissolution. The data for dissolution in $2 \mathrm{M} \mathrm{HNO}_{3} / 0.025 \mathrm{M} \mathrm{KF}$ and $2 \mathrm{~g} / \mathrm{L}$ boron are contained in Table 1. Except where stated, all data reflect unstirred conditions.

Not much can be said about the physical, chemical, and metallurgical properties of each of the materials because little specific information is available for each material type. However, because of the data's end use, specific knowledge about each material is not necessary. The most important aspect of the data is that the material is representative of a material of construction which may be used to fabricate the dissolver bundle end cap.

In assessing which data are applicable, several variables ought to be considered. Among these issues are: 1) sample material; 2) agitation; 3) presence of a coating; 4) temperature; 5) effective dissolution surface area. Although these variables affect 
dissolution rates in a manner expected, they are discussed briefly because they can often be overlooked.

Sample Material: Disregarding the aluminum data, the carbon steel data from Table 1 seem to fall into three basic ranges: plate/bar, wire/rivet, and can material. The roomtemperature, unstirred dissolution rates for the plate/bar materials are between 0.7 and 1.7 $\mathrm{mg} / \mathrm{min}-\mathrm{cm}^{2}$. For wire and rivet samples, the unstirred rates range from 2.1 to 3.2 $\mathrm{mg} / \mathrm{min}-\mathrm{cm}^{2}$. The exception is the \#9 wire which has a large amount of surface corrosion inhibiting dissolution. Uncoated can materials have unstirred room-temperature dissolution rates of 3.4 to $4.0 \mathrm{mg} / \mathrm{min}-\mathrm{cm}^{2}$. The primary difference in rate data is attributable to the fact the samples represent a range of unknown materials with unknown compositions. The data show no correlation between sample hardness and dissolution rates. The density data of Table 1 show that the can materials differ from the plate/bar and wire/rivet materials.

Table 1. Sample Dissolution Rates

\begin{tabular}{|c|c|c|c|c|c|c|}
\hline \multirow[b]{2}{*}{ Sample } & \multicolumn{2}{|c|}{$\begin{array}{c}\text { Rate } \\
\left(\mathrm{mg} / \mathrm{min}-\mathrm{cm}^{2}\right)\end{array}$} & \multirow{2}{*}{$\begin{array}{l}\text { Rockwell } \\
\text { Hardness }\end{array}$} & \multirow{2}{*}{$\begin{array}{l}\text { Thick } \\
\text { (cm) }\end{array}$} & \multirow{2}{*}{$\begin{array}{l}\text { Diam. } \\
\text { (cm) }\end{array}$} & \multirow{2}{*}{\begin{tabular}{|l|} 
Sample \\
Density \\
(g/mL)
\end{tabular}} \\
\hline & $23^{\circ} \mathrm{C}$ & $100^{\circ} \mathrm{C}$ & & & & \\
\hline A: 20 ga carbon steel - corroded & 0.720 & 20.886 & B90 & 0.075 & --- & 7.02 \\
\hline B: 16 ga carbon steel - corroded & 1.658 & 14.965 & T44 ( B72) & 0.141 & --- & 7.67 \\
\hline C: \#9 carbon steel wire - corroded & 0.362 & 22.773 & --- & ---- & 0.384 & 6.96 \\
\hline D: Al rivet (w/ unknown metal shank) & 0.022 & 2.480 & ---- & ---- & 0.193 & 2.70 \\
\hline $\mathrm{E}:$ Al rivet (w/ plastic shank) & 0.002 & 2.138 & ---- & ---- & 0.193 & 3.40 \\
\hline F: Carbon steel rivet & 2.285 & 101.895 & $\mathrm{~F} 26(\sim \mathrm{B} 13)$ & --- & 0.193 & 7.78 \\
\hline F: Carbon steel rivet - no stirring & 2.135 & ---- & $\bar{F} 26(\sim \mathrm{B} 13)$ & $-\overline{---}$ & 0.192 & 7.78 \\
\hline F: Carbon steel rivet - with stirring & 6.658 & ---- & F26 ( B13) & ---- & 0.192 & ---- \\
\hline G: Carbon steel shank & 2.958 & ---- & --- & 0.060 & ---- & ---- \\
\hline $\mathrm{H}:$ Sheared carbon steel nail & 3.209 & ---- & F87 ( B66) & ---- & 0.410 & 7.83 \\
\hline I: Carbon steel weld rod - no stirring & 4.860 & ---- & F66 ( B53) & ---- & 0.319 & 7.68 \\
\hline I: Carbon steel weld rod - with stirring & 16.068 & ---- & F66 ( B53) & ---- & 0.306 & 7.70 \\
\hline $\mathrm{J}$ : Carbon steel plate & 1.161 & ---- & B72 & 0.157 & ---- & 7.74 \\
\hline K: Carbon steel bar & 0.824 & ---- & B67 & 0.308 & --- & 7.56 \\
\hline L: small screw-top lid - Sn coated & 2.488 & ---- & T30 ( B58) & 0.039 & --- & 5.44 \\
\hline L: small screw-top lid - w/o Sn coating & 4.017 & ---- & T25 ( B53) & 0.039 & --- & ---- \\
\hline M: food-pack can - Sn coated & 2.678 & ---- & T41 ( B69) & 0.058 & --- & 5.09 \\
\hline M: food-pack can - w/o Sn coating & 3.702 & ---- & T25 ( B53) & 0.058 & ---- & --- \\
\hline $\mathrm{N}$ : large crimp lid - Sn coated & 2.503 & ---- & T36 ( - B63) & 0.037 & ---- & 4.03 \\
\hline $\mathrm{N}$ : large crimp lid - w/o Sn coating & 3.450 & ---- & T26 ( B54) & 0.037 & --- & ---- \\
\hline
\end{tabular}

Agitation: The effect of stirring is clearly depicted in both Table 1 and Figure 2. The data in Table 1 exhibit a three- to four-fold increase in dissolution rate when stirring is provided. The pictures Figure 2 show some of the reason for the change. As carbon steel dissolves, it forms an oxide that does not readily dissolve in the absence of stirring. The accumulation of iron oxide near the dissolution surface is expected to diminish the overall dissolution rate. When considering the data of Table 1 for application to dissolver 
bundle end cap design, the data for the unstirred condition can be used as the lower boundary for dissolution rate. Because some mixing will be present in the dissolver and since it is expected that iron oxide will fall away from the dissolver bundle end cap, dissolution rates should be higher than those stated for unstirred conditions.

Presence of a Coating: Initial concern existed about whether or not a Sn coating on the surface of packaging cans might significantly inhibit dissolution of the can. The data in Table 1 show that the coating slows the dissolution rate by roughly one-third for the time that the coating remains. However, because the coating is only a few thousandths of an inch thick, the coating is removed within a few minutes at room temperature (and a few seconds at boiling). Therefore, the effect of the Sn coating on the overall time to dissolve the can is negligible.

Temperature: It is known that dissolution rates are strongly dependent upon reaction temperature. Carbon steel dissolution in $2 \mathrm{M} \mathrm{HNO}_{3} / 0.025 \mathrm{M} \mathrm{KF}$ and $2 \mathrm{~g} / \mathrm{L}$ boron is no different. The data of Table 1 show that a carbon steel dissolver bundle end cap might take 30 minutes to several hours at room temperature to dissolve. However, dissolution will be at least an order of magnitude faster once dissolver heating is initiated.

Figure 2. Effect of Agitation

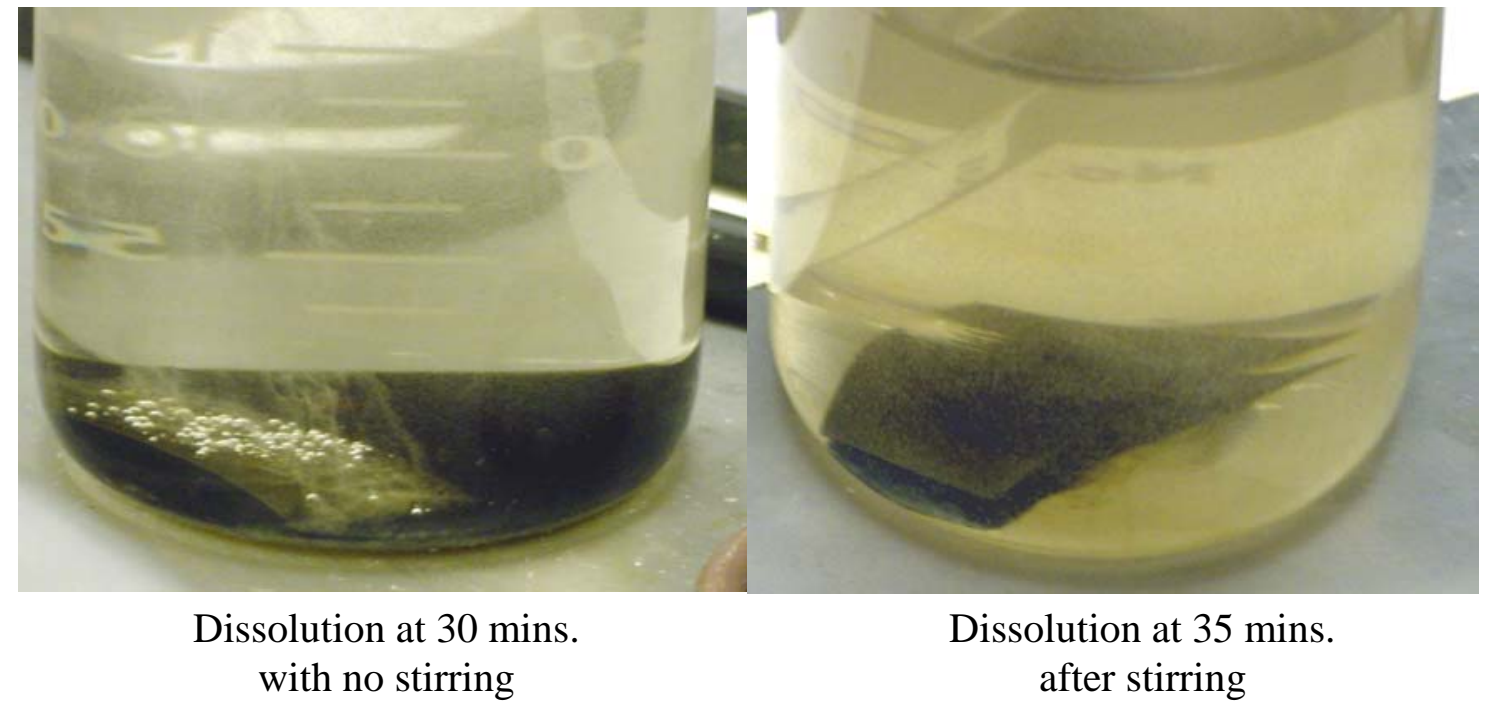

Effective Dissolution Surface Area: When considering the data of Table 1, nothing is more important than considering the effective dissolution surface area and the distance or thickness that must be dissolved for mechanical integrity of the bundle end cap to be breached. For example, a thick piece of steel plate may breach faster than a small rivet because the dissolution of the rivet occurs over a small surface area and the dissolution front must travel a relatively long distance before the rivet loses mechanical integrity.

Carbon Steel Dissolution Gas Generation: Gas generation rates for the dissolution of carbon steel in $2 \mathrm{M} \mathrm{HNO}_{3} / 0.025 \mathrm{M} \mathrm{KF}$ and $2 \mathrm{~g} / \mathrm{L}$ boron reflected those observed for the dissolution of uranium metal. ${ }^{1}$ At room temperature, the amount of gas generated was not 
measurable. The dissolution rate is slow enough that most of the reaction products are soluble in the dissolver solution. At $95^{\circ} \mathrm{C}$, the gas generation rate accelerates and the gases are not dissolved into solution. The measured gas generation was on the order of $250 \mathrm{~mL}$ per gram of carbon steel dissolved.

In both tests, the vessel headspace exhibited the orange-brown fumes indicative of nitrogen dioxide $\left(\mathrm{NO}_{2}\right)$. Nitrogen dioxide exists in equilibrium with nitric oxide (NO) gas. Gas chromatography results show hydrogen concentrations at both test temperatures are below the instrument detection limit of $0.1 \%$. The balance of gases analyzed includes $\mathrm{CO}_{2}$ (the purge gas), air in-leakage during sampling, and an unidentified component (most likely a mixture of $\mathrm{NO}_{2}$ and $\mathrm{NO}$ ). Therefore, based on these data, and the analogous data collected from the dissolution of uranium metal, the balance of gases generated by carbon steel dissolution is primarily NOx.

Effect of MgO on Uranium Metal Dissolution: The dissolution of MgO sand was observed at both room temperature and $100^{\circ} \mathrm{C}$. When $\mathrm{MgO}$ sand was added to $2 \mathrm{M}$ $\mathrm{HNO}_{3} / 0.025 \mathrm{M} \mathrm{KF}$ and $2 \mathrm{~g} / \mathrm{L}$ boron at room temperature, no observable dissolution occurred with five hours. When the solution was heated to $100^{\circ} \mathrm{C}$, greater than $90 \%$ of the $\mathrm{MgO}$ sand dissolved within the first hour. Only the largest grains of sand remained after one hour. After five hours at $100^{\circ} \mathrm{C}$, only trace amounts of residue remained at the bottom of the beaker. It is probable that the residue is impurities other than $\mathrm{MgO}$ that was present in the $\mathrm{MgO}$ sand.

The dissolution rate of uranium metal at room temperature into $2 \mathrm{M} \mathrm{HNO}_{3} / 0.025 \mathrm{M} \mathrm{KF}$ with $2 \mathrm{~g} / \mathrm{L}$ dissolved boron and $1.8 \mathrm{~g} / \mathrm{L}$ dissolved $\mathrm{MgO}$ showed no decrease in dissolution rate due to the presence of dissolved MgO. Duplicate room-temperature measurements yielded dissolution rates of 0.214 and $0.223 \mathrm{mg} / \mathrm{min}-\mathrm{cm}^{2}$. This result is somewhat higher than the $0.137 \mathrm{mg} / \mathrm{min}-\mathrm{cm}^{2}$ measured in the absence of $\mathrm{MgO} .{ }^{1}$ The reason for the significant rate increase is not immediately known. It is possible that synergistic effects are occurring due to the presence of the $\mathrm{MgO}$, but there are insufficient data make any conclusive statements about the rate difference.

\section{CONCLUSIONS}

Several variables related to carbon steel dissolution have been evaluated using various materials that may be used in the fabrication of a dissolver bundle end cap for plutoniumcontaminated scrap processing. The variables evaluated include sample material, agitation, effect of a Sn coating, and temperature. Although, not much can be specifically said about the physical, chemical, and metallurgical properties of each of the materials, the most important aspect of the data is that the material is representative of a material of construction to be used to fabricate the dissolver bundle end cap.

The dissolution data seem to fall into three basic ranges: plate/bar, wire/rivet, and can material. The room temperature, unstirred dissolution rates for the plate/bar materials are between 0.7 and $1.7 \mathrm{mg} / \mathrm{min}-\mathrm{cm}^{2}$. For wire and rivet samples, the unstirred rates range from 2.1 to $3.2 \mathrm{mg} / \mathrm{min}-\mathrm{cm}^{2}$. Uncoated can materials have unstirred room 
temperature dissolution rates of 3.4 to $4.0 \mathrm{mg} / \mathrm{min}-\mathrm{cm}^{2}$. Sample hardness data showed no correlation to the dissolution rates for the three categories. Density data show that the can materials are clearly different from the plate/bar and wire/rivet materials.

Stirring can provide a three- to four-fold increase in dissolution rate when compared to static conditions. As carbon steel dissolves, it forms an oxide that does not readily dissolve in the absence of stirring. The accumulation of iron oxide near the dissolution surface diminishes the overall dissolution rate. Because of the dissolver configuration for the processing of plutonium-contaminated scrap, carbon steel dissolution rates should be higher than those stated for unstirred conditions.

Initial concerns existed about whether or not a Sn coating on the surface of packaging cans might inhibit overall processing rates. The data show that the coating slows the initial dissolution rate by about one-third. However, because the coating is very thin and is removed in a few minutes, the effect of the Sn coating on the overall time to dissolve the can is negligible.

It is known that dissolution rates are strongly dependent upon reaction temperature. The data show that a carbon steel dissolver bundle end cap might take several hours at room temperature to dissolve. However, dissolution will increase at least an order of magnitude once the dissolver is heating to boiling.

Gas generation rates for the dissolution of carbon steel in $2 \mathrm{M} \mathrm{HNO}_{3} / 0.025 \mathrm{M} \mathrm{KF}$ and 2 $\mathrm{g} / \mathrm{L}$ boron reflected those observed for the dissolution of uranium metal. At room temperature, the amount of gas generated was not measurable due to solubility of the reaction products. At $95^{\circ} \mathrm{C}$, the measured gas generation was on the order of $250 \mathrm{~mL}$ per gram of carbon steel dissolved. In both tests, the vessel headspace hydrogen concentration was $<0.1 \%$, which is the instrument detection limit. The balance of gas generated is primarily NOx.

The dissolution of $\mathrm{MgO}$ sand at room temperature in $2 \mathrm{M} \mathrm{HNO}_{3} / 0.025 \mathrm{M} \mathrm{KF}$ and $2 \mathrm{~g} / \mathrm{L}$ boron is very slow. Upon heating to $100^{\circ} \mathrm{C}$, greater than $90 \%$ of the $\mathrm{MgO}$ sand expected to be present dissolves within the first hour. After five hours at $100^{\circ} \mathrm{C}$, only trace amounts of residue remained at the bottom of the beaker. The dissolution rate of uranium metal at room temperature into $2 \mathrm{M} \mathrm{HNO}_{3} / 0.025 \mathrm{M} \mathrm{KF}$ with $2 \mathrm{~g} / \mathrm{L}$ boron and $1.8 \mathrm{~g} / \mathrm{L}$ dissolved $\mathrm{MgO}$ showed no decrease due to the presence of dissolved MgO. Duplicate room temperature measurements yielded dissolution rates of 0.214 and $0.223 \mathrm{mg} / \mathrm{min}-\mathrm{cm}^{2}$, which is higher than the $0.137 \mathrm{mg} / \mathrm{min}-\mathrm{cm}^{2}$ measured in the absence of MgO. The reason for the rate increase may be due to synergistic effects, but not enough data are available to make any conclusive statements.

\section{REFERENCE}

1. R. A. Pierce. "Uranium Metal Dissolution in the Presence of Fluoride and Boron," WSRC-TR-2003-00500 dated November 2003. 
WSRC-TR-2004-00035, Rev. 0

Page 12 
ATTACHMENT 1: Sample Descriptions and Dimensions
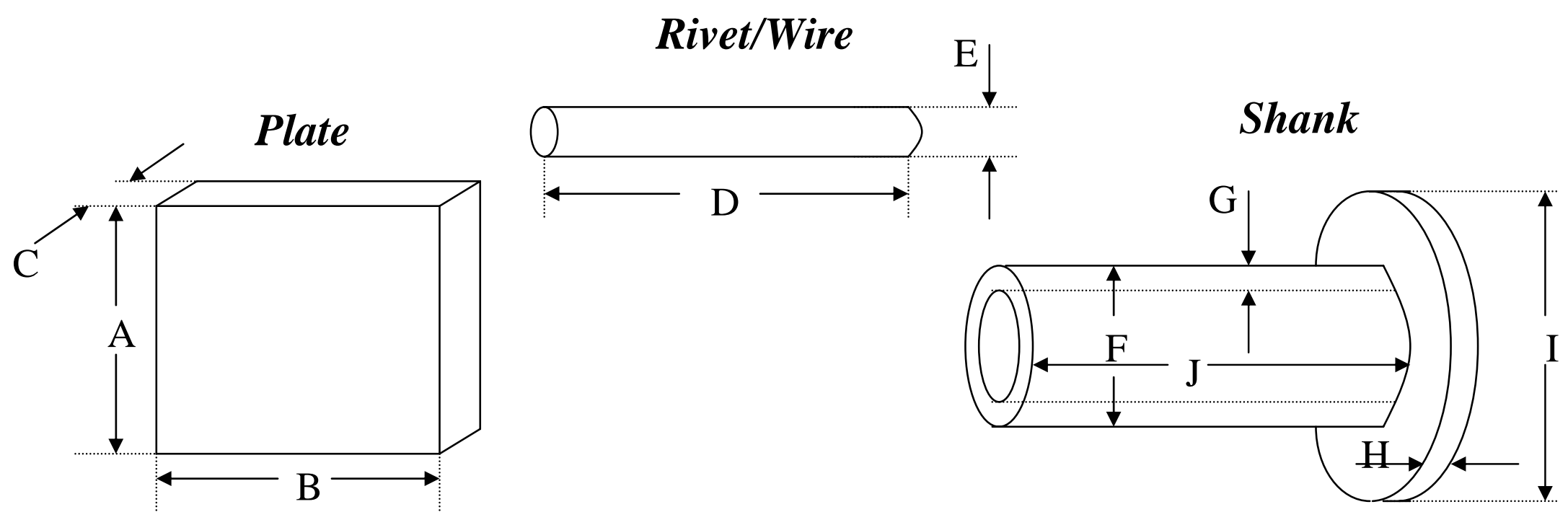

\begin{tabular}{|l|c|c|c|c|c|c|c|c|c|c|c|}
\hline SAMPLE & \multicolumn{7}{|c|}{ DIMENSIONS IN MILLIMETERS } & G & & I \\
\hline & A & B & C & D & E & F & G & H & I & Note \\
\hline A: 20 ga carbon steel plate & 51.12 & 50.60 & 0.75 & & & & & & & & Surface corrosion \\
\hline B: 16 ga carbon steel plate & 51.35 & 50.92 & 1.41 & & & & & & & & Surface corrosion \\
\hline C: \#9 carbon steel wire & & & & 27.42 & 3.84 & & & & & & \\
\hline D1: Al rivet w/ shank & & & & 28.63 & 1.93 & 3.06 & --- & 0.80 & 6.36 & 8.59 & \\
\hline D2: Al rivet & & & & 32.00 & 1.93 & & & & & & \\
\hline E: Al rivet w/ plastic shank & & & & 22.87 & 1.93 & & & & & & \\
\hline F: Carbon steel rivet & & & & 22.91 & 1.93 & & & & & & \\
\hline G: Carbon steel shank & & & & & & 3.19 & 0.60 & 0.95 & 6.36 & 10.48 & \\
\hline H: Sheared carbon steel nail & & & & 81.58 & 4.10 & & & & & & \\
\hline I: Carbon steel weld rod & & & & 59.57 & 3.19 & & & & & & \\
\hline J: Carbon Steel plate & 51.71 & 51.31 & 1.57 & & & & & & & & \\
\hline K: Bar stock & 44.79 & 19.26 & 0.31 & & & & & & & & \\
\hline L: small screw-top lid - flat & 50.57 & 18.22 & 0.39 & & & & & & & & \\
\hline M: large crimp lid - flat & 48.81 & 19.76 & 0.37 & & & & & & & & \\
\hline N: food-pack can - flat & 52.40 & 15.86 & 0.58 & & & & & & & & \\
\hline
\end{tabular}

